\title{
KEEFEKTIFAN MEDIA POWERPOINT TANPA ANIMASI DAN POWERPOINT BERANIMASI TIDAK KOHEREN DALAM PEMBELAJARAN MENULIS LAPORAN
}

\author{
Puji Kurniawan dan Tadkiroatun Musfiroh \\ SMP Negeri 2 Kawunganten, Universitas Negeri Yogyakarta \\ Email: pujikurnia1@yahoo.co.id/itadzuny@yahoo.co.id
}

\begin{abstract}
ABSTRAK
Penelitian ini bertujuan untuk mengungkapkan: (1) keefektifan media Powerpoint tanpa animasi, (2) keefektifan media Powerpoint beranimasi tidak koheren, (3) perbedaan keefektifan antara media Powerpoint tanpa animasi dan media Powerpoint beranimasi tidak koheren, (4) perbedaan hasil belajar antara peserta didik sekolah level rendah dan peserta didik sekolah level tinggi, dan (5) interaksi antara media dan level sekolah, dalam pembelajaran menulis laporan di kelas VIII SMP. Penelitian ini merupakan eksperimen semu dengan desain faktorial sederhana. Populasi penelitian ini meliputi seluruh peserta didik kelas VIII SMP Negeri 1 Kawunganten dan peserta didik kelas VIII SMP Sultan Agung Kawunganten di Kabupaten Cilacap. Dua kelas dari tiap sekolah ditentukan sebagai sampel dengan teknik cluster sampling. Kesimpulan penelitian ini adalah sebagai berikut. (1) Media Powerpoint tanpa animasi efektif digunakan dalam pembelajaran menulis laporan (2) Media Powerpoint beranimasi tidak koheren efektif digunakan dalam pembelajaran menulis laporan. (3) Ada perbedaan keefektifan yang signifikan antara media Powerpoint tanpa animasi dan media Powerpoint beranimasi tidak koheren. (4) Ada perbedaan yang signifikan antara hasil belajar peserta didik sekolah level tinggi dan peserta didik sekolah level rendah. (5) Dalam pembelajaran menulis laporan pada peserta didik kelas VIII SMP, tidak terdapat interaksi yang signifikan antara media dan level sekolah.
\end{abstract}

Kata Kunci: keefektifan, media Powerpoint tanpa animasi, media Powerpoint beranimasi tidak koheren, menulis laporan

\section{THE EFFECTIVENESS OF POWERPOINT WITHOUT ANIMATION AND POWERPOINT WITH INCOHERENT ANIMATION IN THE LEARNING OF REPORT WRITING}

\begin{abstract}
This research aims to reveal: (1) the effectiveness of Powerpoint without animation (2) the effectiveness of Powerpoint with incoherent animation (3) the difference between the effectiveness of Powerpoint without animation and the effectiveness of Powerpoint with incoherent animation, (4) the difference in achievements of students of low level and high level schools, and (5) the interaction between media and school levels in the learning of report writing of junior high school students of grade VIII. This research is a pseudo experiment with simple factorial designs. The research population is the grade VIII students of SMP Negeri 1 Kawunganten and SMP Sultan Agung Kawunganten in Cilacap. Two classes of each school were used as sampling units by using cluster sampling. The cocnclusions of the research are as follows. (1) Powerpoint without animation is effective to be used in the learning of report writing. (2) Powerpoint with incoherent animation is effective to be used in the learning of report writing. (3) There is a significant difference between the effectiveness of Powerpoint without animation and Powerpoint with incoherent animation. (4) There is a significant difference between the learning achievements of students of high level and low level schools. (5) In the learning of report writing of grade VIII students of junior high schools, there is no significant interaction between media and school levels.
\end{abstract}

Keywords: effectiveness, Powerpoint media without animation, Powerpoint media with incoherent animation, report writing 


\section{PENDAHULUAN}

Menulis merupakan keterampilan berbahasa yang penting untuk dikuasai peserta didik. Keterampilan ini tidak hanya dibutuhkan untuk memenuhi kompetensi dasar dalam pembelajaran Bahasa Indonesia tetapi juga dibutuhkan dalam melaksanakan tugas pada mata pelajaran yang lain.

Berbagai keterampilan menulis diajarkan di tingkat SMP. Salah satunya adalah menulis laporan. Kemampuan menulis laporan perlu diajarkan karena keterampilan ini diperlukan peserta didik dalam melaksanakan berbagai tugas di sekolah.

Dibandingkan dengan keterampilan menulis yang lain, seperti menulis puisi dan surat, bagi peserta didik SMP keterampilan menulis laporan tergolong materi baru. Keterampilan ini baru diajarkan di kelas VIII. Mengingat materi ini merupakan hal baru, diduga peserta didik belum memiliki pengetahuan yang cukup dalam hal laporan dan teknik penulisannya. Oleh karena itu, sudah selayaknya jika pembelajaran menulis laporan dirancang dan dilakukan dengan baik. Pembelajaran yang baik memungkinkan peserta didik untuk menguasai konsep tentang penulisan laporan dan mampu menggunakannya dalam praktik menulis.

Dalam pembelajaran menulis laporan, kegiatan utama peserta didik adalah latihan/ praktik menulis. Peserta didik diharapkan mampu menguasai kemampuan menulis laporan dengan melakukan banyak latihan. Pada kegiatan tersebut peserta didik secara aktif mempelajari cara menulis laporan dan langsung mempraktikkannya.

Peserta didik belajar secara aktif. Guru berperan sebagai pembimbing atau fasilitator sebelum dan selama kegiatan menulis berlangsung. Dalam menjalankan peran tersebut, ada beberapa cara yang dapat dilakukan guru, salah satunya adalah pemberian materi tentang laporan dan teknik menulisnya sebelum kegiatan menulis dilakukan. Materi tersebut dapat berguna sebagai bekal peserta didik dalam praktik menulis.

Penyampaian materi dapat dilakukan dengan menggunakan media pembelajaran. Kemp \& Dayton (1985: 3-4) menyatakan bahwa penggunaan media dapat membuat pembelajar- an menjadi lebih standar, menarik, interaktif, efisien, fleksibel dari segi waktu/tempat, dan dapat meningkatkan sikap positif siswa maupun pengajar.

Ada berbagai macam media yang dapat digunakan, termasuk media presentasi berbasis komputer seperti Powerpoint, Corel presentation, dan Macromedia. Di antara ketiga program itu, yang paling populer adalah Powerpoint (Indriana, 2011: 15).

Powerpoint memiliki berbagai kelebihan. Media ini dapat digunakan untuk menjelaskan materi yang bersifat teoretis, dapat digunakan dalam pembelajaran klasikal, memiliki jangkauan pancar cukup besar karena menggunakan proyektor, dan dapat mengakomodasi siswa yang memiliki tipe visual, auditif, dan kinestetik (Rusman, Kurniawan, \& Riyana, 2012: 67).

Kelebihan lain yang dimiliki Powerpoint adalah kemampuannya menampilkan objek dinamis. Salah satu objek dinamis yang dapat ditampilkan media ini adalah animasi. Dengan Powerpoint, guru/penyaji materi dapat membuat transisi slide, teks animasi dan objek/ gambar animasi.

Dalam penelitian ini, yang dimaksud Powerpoint beranimasi tidak koheren adalah Powerpoint yang menampilkan ketiga jenis animasi tersebut. Slide berisi teks, gambar, dan animasi yang gerakan-gerakannya tidak memiliki relevansi dengan isi/materi pelajaran. Adapun Powerpoint tanpa animasi adalah Powerpoint yang hanya menampilkan teks dan gambar.

Powerpoint tanpa animasi memiliki kelebihan dalam hal koherensi. Slide yang berisi teks dan gambar yang koheren memiliki kesesuaian dengan prinsip multimedia dan prinsip koherensi.

Powerpoint beranimasi tidak koheren memiliki kelebihan dalam hal menarik perhatian peserta didik. Arsyad (2013, p.188) menyatakan bahwa animasi dalam Powerpoint dapat membuat presentasi menjadi lebih hidup, lebih berkarakter, dan lebih menarik. Gerakangerakan teks atau objek dapat menarik peserta didik untuk melihat atau memperhatikan slide yang ditampilkan.

Yang menjadi pertanyaan adalah apakah peningkatan perhatian peserta didik karena ada- 
nya animasi dalam pembelajaran menulis laporan juga diimbangi dengan peningkatan hasil belajarnya? Pertanyaan itu terutama ditujukan pada penggunaan animasi yang tidak koheren.

Prinsip-prinsip multimedia yang disampaikan Mayer (2009, p.167), yang salah satunya adalah prinsip koherensi, dapat dijadikan rujukan dalam menjawab pertanyaan tersebut. Berdasarkan prinsip koherensi, multimedia yang memiliki kata-kata dan gambar yang koheren lebih efektif dibandingkan dengan multimedia yang unsur-unsurnya tidak koheren.

Faktor lain yang perlu diperhatikan dalam penggunaan media adalah pengetahuan peserta didik. Mayer $(2009$, p.235) menyatakan "Pengaruh desain media lebih kuat bagi murid-murid berpengetahuan rendah daripada murid-murid berpengetahuan tinggi, dan bagi murid-murid dengan kemampuan spatial tinggi daripada spatial rendah." Hal itu disebut dengan prinsip perbedaan individual. Suatu media dapat efektif pada kelompok tertentu, dan dapat kurang efektif pada kelompok yang lain karena adanya perbedaan pengetahuan dan kemampuan di antara peserta didik.

Berdasarkan pernyataan tersebut, dalam pembelajaran menulis laporan dimungkinkan terdapat perbedaan keefektifan media Powerpoint antara slide tanpa animasi dan slide beranimasi tidak koheren. Dengan media yang sama, hasil belajar peserta didik sekolah level tinggi dimungkinkan berbeda dengan hasil belajar sekolah level rendah. Dengan kata lain, selain media, level sekolah diduga mempengaruhi hasil pembelajaran. Selain itu, dalam pembelajaran menulis laporan menggunakan media Powerpoint, diduga terjadi interaksi antara media dan level sekolah.

\section{METODE}

Jenis Penelitian

Penelitian ini merupakan penelitian eksperimen semu. Kelas yang digunakan sebagai sampel penelitian tidak diubah. Jadwal pelajaran juga tidak diubah.

\author{
Waktu dan Tempat Penelitian \\ Penelitian dilakukan di SMP Negeri 1 \\ Kawunganten dan SMP Sultan Agung Kawung-
}

anten. Kedua sekolah tersebut berada wilayah Kabupaten Cilacap, Provinsi Jawa Tengah.

SMP Negeri 1 Kawunganten termasuk dalam level tinggi sedangkan SMP Sultan Agung termasuk dalam level rendah. Penentuan level dilakukan atas dasar nilai rata-rata Ujian Nasional Tahun 2012. Nilai rata-rata Ujian Nasional seluruh SMP di Kabupaten Cilacap diurutkan dari nilai tertinggi ke nilai terendah. Selanjutnya urutan nilai tersebut dibagi menjadi tiga bagian, yaitu $27,5 \%$ urutan atas menjadi kelompok tinggi dan $27,5 \%$ urutan bawah menjadi kelompok rendah. Penentuan angka 27,5\% ini diadaptasikan dari penentuan kelompok tinggi dan rendah dalam analisis butir soal. Nurgiyantoro (2012: 192-193) menyatakan bahwa kelompok tinggi diambil dari $27,5 \%$ peserta yang skornya tinggi dan kelompok rendah diambil dari $27,5 \%$ peserta didik yang skornya rendah. Sebelum pengambilan itu, peserta didik diurutkan dulu dari skor tertinggi sampai yang terendah.

Pada tahun 2012, di Kabupaten Cilacap terdapat 196 SMP. Jumlah sekolah kelompok tinggi berarti $27,5 \%$ dari 196 sekolah, yaitu 53,90 (dibulatkan menjadi 54). Jumlah sekolah kelompok rendah berarti juga 54 sekolah. Dengan demikian, kelompok tinggi terdiri atas sekolah-sekolah yang memiliki peringkat 1 sampai dengan 54, dan sekolah kelompok rendah memiliki peringkat antara 142 sampai dengan 196.

Dalam pemilihan dua sekolah dari sekolah kelompok tinggi dan sekolah kelompok rendah tersebut, didapat SMP Negeri 1 Kawunganten dan SMP Sultan Agung Kawunganten. SMP 1 Kawunganten yang memiliki peringkat 36 pada Tahun 2012, menjadi sekolah level tinggi dan SMP Sultan Agung yang memiliki peringkat 154 menjadi sekolah level rendah.

Selain karena faktor nilai Ujian Nasional, penggunaan kedua sekolah tersebut sebagai tempat penelitian dipandang tepat karena kedua sekolah tersebut belum pernah melaksanakan pembelajaran Bahasa Indonesia menggunakan media Powerpoint. Dengan demikian, dari aspek media kedua sekolah tersebut dalam kondisi yang sama.

Penelitian ini dilaksanakan pada semester 1 Tahun Pelajaran 2013/2014, bulan Oktober 
2013 sampai dengan Desember 2013. Tatap muka di kelas pada tiap kelompok dilakukan lima kali. Pertemuan pertama untuk pretest, pertemuan kedua sampai dengan keempat untuk pembelajaran, dan pertemuan kelima untuk posttest.

\section{Populasi dan Sampel}

Populasi penelitian ini adalah seluruh peserta didik kelas VIII di SMP Negeri 1 Kawunganten dan SMP Sultan Agung Kawunganten, tahun pelajaran 2013/2014. Jumlah peserta didik kelas VIII SMP Negeri 1 Kawunganten berjumlah 252 anak, sedangkan jumlah peserta didik kelas VIII SMP Sultan Agung berjumlah 92 anak. Jumlah populasi keseluruhan dari dua sekolah berjumlah 344 peserta didik.

Dari populasi tersebut, diambil empat kelas untuk menjadi sampel penelitian. Penentuannya menggunakan teknik cluster random sampling. Tiap sekolah diambil dua kelas untuk dijadikan kelompok kontrol dan kelompok eksperimen. Dua kelas yang telah terpilih kemudian diundi lagi untuk menentukan kelas yang dijadikan kelompok eksperimen dan kelas yang dijadikan kelompok kontrol.

Dari proses tersebut, di SMP Negeri 1 Kawunganten kelas yang terpilih adalah kelas 8Adan 8D. Kelas 8A sebagai kelompok eksperimen dan kelas 8D sebagai kelompok kontrol. Adapun di SMP Sultan Agung kelas yang terpilih adalah kelas $8 \mathrm{~A}$ dan $8 \mathrm{C}$. Kelas $8 \mathrm{~A}$ menjadi kelompok kontrol dan $8 \mathrm{C}$ menjadi kelompok eksperimen.

Kelas 8Adan 8D SMPNegeri 1 Kawunganten masing-masing memiliki jumlah peserta didik 36 anak. Kelas 8A SMP Sultan Agung memiliki peserta didik 28 anak dan kelas 8C SMP Sultan Agung memiliki peserta didik 31 anak.

Dari jumlah itu, tiap kelas diambil 27 peserta didik secara acak untuk menjadi sampel penelitian. Jadi jumlah sampel dalam penelitian ini adalah 108 peserta didik.

Prosedur

Selain menguji keefektifan media, penelitian ini juga menguji interaksi antara media dan level sekolah. Oleh karena itu, desain penelitian yang digunakan adalah desain faktorial sederhana. Berikut tabel desain faktorial dalam penelitian ini.

Tabel 1. Desain Penelitian

\begin{tabular}{ccc}
\hline \multirow{2}{*}{ Level } & \multicolumn{2}{c}{ Media } \\
\cline { 2 - 3 } Sekolah & Powerpoint & $\begin{array}{c}\text { Powerpoint } \\
\text { Tanpa Animasi }\end{array}$ \\
$\begin{array}{c}\text { Beranimasi } \\
\text { Tidak Koheren }\end{array}$ \\
\hline \multirow{2}{*}{ Tinggi } & Kelompok & Kelompok \\
& Eksperimen & Kontrol \\
Rendah & Kelompok & Kelompok \\
& Eksperimen & Kontrol \\
\hline
\end{tabular}

Sebelum tindakan penelitian dilakukan, keempat kelompok diberi tes awal terlebih dahulu. Tes awal ini dilakukan untuk mengetahui kemampuan awal tiap kelompok. Setelah perlakukan penelitian dilaksanakan, kedua kelompok tersebut diberi tes akhir.

Untuk mendapatkan hasil penelitian yang valid, tahapan tersebut dilakukan dengan mempertimbangkan faktor-faktor internal dan eksternal yang dapat mempengaruhi kemurnian hasil penelitian. Artinya, validitas eksternal dan internal diperhatikan.

Validitas internal diupayakan dengan mengatasi faktor-faktor internal yang dapat mempengaruhi hasil penelitian. Champbell (1966, p.5) menyatakan bahwa faktor-faktor internal tersebut meliputi (1) sejarah, (2) pematangan, (3) pemberian pratest, (4) alat pengukuran, (5) kemunduran statistik, (6) pemilihan subjek yang berbeda, (7) hilang dalam eksperimen, dan (8) interaksi pematangan dengan seleksi.

Dalam penelitian ini, faktor-faktor yang dapat mempengaruhi hasil penelitian tersebut diatasi dengan berbagai cara. Unsur sejarah dan pematangan diantisipasi dengan melakukan penelitian tidak lebih dari tiga bulan. Pratest dilakukan pada semua kelompok sehingga apabila ada pengaruh pratest terjadi pada semua kelompok, yang artinya keseimbangan antarkelompok terjaga. Alat pengukuran dan media yang digunakan valid. Kelompok eksperimen dan kelompok kontrol dipilih secara acak dari kelas-kelas yang memiliki kemampuan yang berimbang.

Validitas eksternal diupayakan dengan tiga cara. Pertama, penelitian dilakukan de- 
ngan suasana yang alamiah. Kedua, siswa tidak diberitahu kalau sedang menjadi subjek penelitian. Ketiga, eksperimen dilakukan dengan tidak mengubah jadwal pelajaran yang ada.

Data, Instrumen, dan Teknik Pengumpulan Data

Data penelitian ini yaitu nilai pretest dan posttest peserta didik. Teknik pengumpulan data dalam penelitian ini adalah penugasan (nontes). Peserta didik diminta untuk mengamati suatu objek dan melaporkannya secara tertulis. Penugasan ini diberikan sebelum dan sesudah perlakukan penelitian dilakukan. Penugasan ini digunakan untuk mendapatkan data mengenai kemampuan menulis laporan peserta didik. Data yang lain, misalnya data nilai hasil Ujian Nasional, nama siswa, jumlah siswa, dan sebagainya diperoleh dengan mempelajari dokumen sekolah.

Instrumen yang digunakan dalam penelitian ini adalah panduan melaksanakan tugas, lembar kerja siswa, rubrik penilaian, dan lembar penilaian. Semua instrumen disusun berdasarkan standar kompetensi dan kompetensi dasar yang ada dalam Kurikulum Tingkat Satuan Pendidikan.

Instrumen tersebut digunakan untuk mendapatkan data kemampuan menulis peserta didik. Panduan melaksanakan tugas berisi langkah-langkah yang harus dilaksanakan peserta didik dalam melakukan pangamatan dan penulisan laporan. Hasil pengamatan dan laporan ditulis dalam lembar kerja. Rubrik penilaian digunakan sebagai panduan guru dalam melakukan penilaian. Hasil penilaian ditulis dalam lembar penilaian.

\section{Teknik Analisis Data}

Sebelum data hasil penelitian dianalisis, terlebih dahulu dilakukan uji prasyarat. Ada dua pengujian yang dilakukan, yaitu uji homogenitas dan uji normalitas.

Uji homogenitas dilakukan untuk mengetahui apakah data yang akan diuji statistik bersifat homogen. Analisis data dilakukan apabila kedua hasil tes homogen. Uji homogenitas dilakukan dengan uji Levene menggunakan program SPSS 16.

Uji normalitas dilakukan untuk mengetahui normalitas data. Uji normalitas dilakukan dengan uji Kolmogorov-Smirnov (Ghozali, 2009: 30)

Uji hipotesis ini dilakukan dengan uji-t sampel berhubungan dan uji anava dua arah. Uji- $t$ sampel berhubungan digunakan untuk menguji perbedaan nilai pretest dan posttest, baik pada peserta didik yang belajar melalui media Powerpoint tanpa animasi maupun peserta didik yang belajar melalui media Powerpoint beranimasi tidak koheren. Dengan kata lain, uji- $t$ digunakan untuk menguji hipotesis 1 dan hipotesis 2 .

Anava dua arah digunakan untuk menguji hipotesis 3, hipotesis 4, dan hipotesis 5 . Yang diuji meliputi (1) perbedaan kemampuan menulis laporan antara peserta didik yang menggunakan media Powerpoint tanpa animasi dan peserta didik yang belajar dengan media Powerpoint beranimasi tidak koheren, (2) perbedaan hasil belajar antara peserta didik sekolah level rendah dan peserta didik dari sekolah level tinggi, dan (3) interaksi antara media dan level sekolah.

\section{HASIL DAN PEMBAHASAN}

Data hasil penelitian ini berupa nilai pretest dan nilai posttest peserta didik kelas VIII A dan VIII D SMP Negeri 1 Kawunganten, serta kelas VIII A dan VIII C SMP Sultan Agung Kawunganten. Nilai pretest merupakan hasil penilaian terhadap naskah laporan peserta didik yang digunakan untuk mengetahui kemampuan awal peserta didik sebelum tindakan penelitian dilakukan. Adapun nilai posttest didapatkan dari penilaian terhadap naskah laporan yang disusun peserta didik setelah mendapatkan pembelajaran (tindakan penelitian).

Deskripsi Nilai Pretest Kelompok Eksperimen Kelas yang belajar menulis laporan melalui media Powerpoint tanpa animasi yaitu kelas VIII A SMP Negeri 1 Kawunganten dan kelas VIII C SMP Sultan Agung Kawunganten. Tiap kelas diambil 27 peserta didik sebagai sampel. Jumlah sampel kelompok ini 54 peserta didik.

Nilai rata-rata pretest dari peserta didik yang menggunakan Powerpoint tanpa animasi sebesar 67,14. Standar deviasinya sebesar 4,96. 
Nilai tertinggi sebesar 77,00 dan yang terendah sebesar 56,00.

Nilai tersebut merupakan nilai gabungan kelas VIII A SMP Negeri 1 Kawunganten dan VIII C SMP Sultan Agung Kawunganten. Berikut ini tabel nilai pretest tiap kelas.

Tabel 2. Nilai Pretest Kelas VIII A SMP N 1 Kawunganten dan VIII C SMP Sultan Agung

\begin{tabular}{lcc}
\hline \multirow{1}{*}{ Nilai } & $\begin{array}{l}\text { Kelas VIII A } \\
\text { SMP N 1 } \\
\text { Kawunganten }\end{array}$ & $\begin{array}{l}\text { Kelas VIII C } \\
\text { SMP } \\
\text { Sultan Agung }\end{array}$ \\
\hline Terendah & 59,50 & 56,00 \\
Tertinggi & 77,00 & 75,00 \\
Rata-rata & 68,41 & 65,87 \\
Std. Deviasi & 4,58 & 5,09 \\
\hline
\end{tabular}

Pada tabel tampak bahwa nilai kelas VIII A SMP Negeri 1 Kawunganten lebih tinggi dari nilai kelas VIII C SMP Sultan Agung Kawunganten. Kelas VIII A SMP Negeri 1 Kawunganten memiliki nilai rata-rata 68,41 sedangkan kelas VIII C SMP Sultan Agung memiliki nilai rata-rata 65,87 . Keduanya memiliki perbedaan nilai rata-rata sebesar 2,54.

Nilai tertinggi dan terendah tiap kelas juga tidak sama. Kelas VIII A SMP Negeri 1 Kawunganten memiliki nilai tertinggi sebesar 77,00 dan nilai terendah sebesar 59,50. Kelas VIII C SMP Sultan Agung Kawunganten memiliki nilai tertinggi sebesar 75,00 dan nilai terendah sebesar 56,00 .

Deskripsi Nilai Pretest Kelompok Kontrol

Pembelajaran menulis laporan menggunakan media Powerpoint beranimasi tidak koheren dilaksanakan di kelas VIII D SMP Negeri 1 Kawunganten dan kelas VIII A SMP Sultan Agung Kawunganten. Tiap kelas diambil 27 peserta didik sebagai sampel penelitian. Jadi, jumlah sampel pada pembelajaran menulis laporan menggunakan media Powerpoint beranimasi tidak koheren 54 peserta didik.

Nilai rata-rata pretest kelompok kontrol sebesar 67,26 dan standar deviasinya sebesar 5,29. Nilai laporan tertinggi sebesar 79,50 dan nilai terendahnya sebesar 57,50.

Kelompok kotrol terdiri atas kelas VIII D SMP Negeri 1 Kawunganten dan kelas VIII
A SMP Sultan Agung. Berikut ini tabel nilai pretest tiap kelas.

Tabel 3. Nilai Pretest Kelas VIII D SMP N 1 Kawunganten dan VIII A SMP Sultan Agung

\begin{tabular}{lcc}
\hline Nilai & $\begin{array}{l}\text { Kelas VIII D } \\
\text { SMP N 1 } \\
\text { Kawunganten }\end{array}$ & $\begin{array}{l}\text { Kelas VIII A } \\
\text { SMP } \\
\text { Sultan Agung }\end{array}$ \\
\hline Terendah & 59,50 & 57,50 \\
Tertinggi & 79,50 & 75,00 \\
Rata-rata & 68,35 & 66,17 \\
Std. Deviasi & 5,21 & 5,24 \\
\hline
\end{tabular}

Nilai rata-rata kedua kelas tersebut tidak sama. Kelas VIII D SMP Negeri 1 Kawunganten memperoleh nilai rata-rata sebesar 68,35 sedangkan kelas VIII A SMP Sultan Agung Kawunganten mendapatkan nilai rata-rata sebesar 66,17. Selisih kedua nilai tersebut sebesar 2,18 .

Nilai tertinggi dan terendah tiap kelas juga tidak sama. Kelas VIII D SMP Negeri 1 Kawunganten memiliki nilai tertinggi sebesar 79,50 dan nilai terendah sebesar 59,50. Kelas VIII A SMP Sultan Agung Kawunganten memiliki nilai tertinggi sebesar 75,00 dan nilai terendah sebesar 57,50.

Deskripsi Nilai Posttest Kelompok Eksperimen Nilai rata-rata posttest peserta didik yang menggunakan media Powerpoint Tanpa animasi sebesar 75,29. Standar deviasinya sebesar 4,912. Nilai tertinggi sebesar 85,50 dan yang terendah sebesar 65,50 .

Nilai tersebut merupakan nilai gabungan dari dua kelas yang menjadi kelompok eksperimen. Nilai tiap kelas tertuang dalam tabel berikut.

Tabel 4. Nilai Postest Kelas VIII A SMP N 1 Kawunganten dan VIII C SMP Sultan Agung

\begin{tabular}{lcc}
\hline Nilai & $\begin{array}{l}\text { Kelas VIII A } \\
\text { SMP N 1 } \\
\text { Kawunganten }\end{array}$ & $\begin{array}{l}\text { Kelas VIII C } \\
\text { SMP } \\
\text { Sultan Agung }\end{array}$ \\
\hline Terendah & 69,00 & 65,50 \\
Tertinggi & 85,50 & 80,00 \\
Rata-rata & 77,52 & 73,06 \\
Std. Deviasi & 4,68 & 4,12 \\
\hline
\end{tabular}


Pada tabel tampak bahwa rata-rata nilai posttest kelas VIII A SMP Negeri 1 Kawunganten lebih tinggi dari nilai rata-rata kelas VIII C SMP Sultan Agung Kawunganten. Kelas VIII A SMP Negeri 1 Kawunganten memiliki nilai rata-rata 77,52 sedangkan kelas VIII C SMP Sultan Agung memiliki nilai rata-rata 73,06. Keduanya memiliki perbedaan nilai rata-rata sebesar 4,46.

Kedua kelas memiliki capaian nilai tertinggi yang berbeda. Nilai tertinggi kelas VIII A SMP Negeri 1 Kawunganten sebesar 85,50. Adapun kelas VIII C SMP Sultan Agung Kawunganten memiliki nilai tertinggi sebesar 80,00 .

Nilai terendah dari dua kelas tersebut juga berbeda. Nilai terendah kelas VIII A SMP Negeri 1 Kawunganten sebesar 69,00. Adapun kelas VIII C SMP Sultan Agung Kawunganten memiliki nilai terendah sebesar 65,50.

\section{Deskripsi Nilai Posttest Kelompok Kontrol}

Nilai rata-rata posttest kelompok kontrol sebesar 73,11 dan standar deviasinya sebesar 5,55. Nilai laporan tertinggi sebesar 87,50 dan nilai terendahnya sebesar 61,50 .

Nilai tersebut merupakan nilai gabungan dari dua kelas yang menjadi kelompok kontrol. Nilai postest tiap kelas tercantum dalam tabel berikut.

Tabel 5. Nilai Posttest Kelas VIII D SMP N 1 Kawunganten dan VIII A SMP Sultan Agung

\begin{tabular}{lcc}
\hline Nilai & $\begin{array}{l}\text { Kelas VIII D } \\
\text { SMP N 1 } \\
\text { Kawunganten }\end{array}$ & $\begin{array}{l}\text { Kelas VIII A } \\
\text { SMP } \\
\text { Sultan Agung }\end{array}$ \\
\hline Terendah & 68,00 & 61,50 \\
Tertinggi & 87,50 & 81,00 \\
Rata-rata & 76,35 & 69,87 \\
Std. Deviasi & 4,51 & 4,54 \\
\hline
\end{tabular}

Nilai rata-rata kedua kelas tersebut tidak sama. Kelas VIII D SMP Negeri 1 Kawunganten memperoleh nilai rata-rata sebesar 76,35 sedangkan kelas VIII A SMP Sultan Agung Kawunganten mendapatkan nilai rata-rata sebesar 69,87 . Selisih kedua nilai tersebut sebesar 6,48 .
Nilai tertinggi dan terendah kedua kelas tidak sama. Capaian nilai tertinggi Kelas VIII D SMP Negeri 1 Kawunganten lebih baik daripada kelas VIII A SMP Sultan Agung Kawunganten. Nilai tertinggi kelas VIII D SMP Negeri 1 Kawunganten sebesar 87,50 dan nilai terendahnya sebesar 68,00. Kelas VIII A SMP Sultan Agung Kawunganten memiliki nilai tertinggi sebesar 81,00 dan nilai terendah sebesar 61,50 .

\section{Hasil Uji Prasyarat}

Hipotesis diuji dengan uji-t dan Anova dua arah. Sebelum uji statistik tersebut dilakukan, data diuji normalitas dan homogenitasnya.

Hasil uji normalitas menunjukkan nilai pretest semua kelas berdistribusi normal. Kelas VIII A dan VIII D SMP Negeri 1 Kawunganten memiliki nilai statistik sebesar 0,138 dan 0,152 yang masing-masing signifikan pada taraf 0,200 dan 0,109. Kelas VIII A dan VIII C SMP Sultan Agung memiliki nilai statistik sebesar 0,119 dan 0,087 yang keduanya signifikan pada taraf 0,200 .

Nilai posttest semua kelas berdistribusi normal. Kelas VIII A dan VIII D SMP Negeri 1 Kawunganten memiliki nilai statistik sebesar 0,112 dan 0,105 yang keduanya signifikan pada taraf 0,200. Kelas VIII A dan VIII C SMP Sultan Agung memiliki nilai statistik sebesar 0,149 dan 0,133 yang masing-masing signifikan pada taraf 0,131 dan 0,200 .

Hasil uji homogenitas menunjukkan bahwa semua kelas memiliki nilai yang homogen. Pada nilai pretest, hasil uji homogenitas menunjukkan nilai Levene Statistic sebesar 0,713 dan signifikan pada taraf 0,546 (based on mean). Adapun pada nilai posttest, hasil uji homogenitas menunjukkan nilai Levene Statistic sebesar 0,358 dan signifikan pada taraf 0,783 (based on mean).

Keefektifan Media Powerpoint Tanpa Animasi Dalam penelitian ini, media Powerpoint tanpa animasi digunakan dalam pembelajaran menulis laporan di kelas VIII A SMP Negeri 1 Kawunganten dan VIII C SMP Sultan Agung Kawunganten. Keefektifan media ini diukur dari perbedaan kemampuan menulis laporan pe- 
serta didik sebelum pembelajaran menggunakan media Powerpoint tanpa animasi dilakukan dan sesudah pembelajaran dilakukan. Intinya, dilihat perbedaan kemampuan awal dan kemampuan akhirnya.

Kemampuan awal peserta didik ditunjukkan oleh hasil pretest sedangkan kemampuan akhir ditunjukkan oleh hasil posttest. Hasil uji beda kedua nilai tersebut menunjukkan tingkat efektivitas media.

Nilai rata-rata pretest didapatkan dari jumlah nilai seluruh peserta didik dari kedua kelas dibagi jumlah peserta didik. Hasilnya sebesar 67,14 . Nilai rata-rata posttest didapatkan dengan cara yang sama. Hasilnya sebesar 75,29 .

Selisih nilai rata-rata pretest dan nilai rata-rata posttest sebesar 8,15 . Nilai posttest lebih tinggi daripada nilai pretest. Artinya, ada peningkatan nilai. Hal itu menjadi indikator awal keefektifan media Powerpoint tanpa animasi dalam pembelajaran menulis laporan pada peserta didik kelas VIII SMP. Berikut ini grafik yang menggambarkan perbedaan nilai pretest dan posttest tersebut.

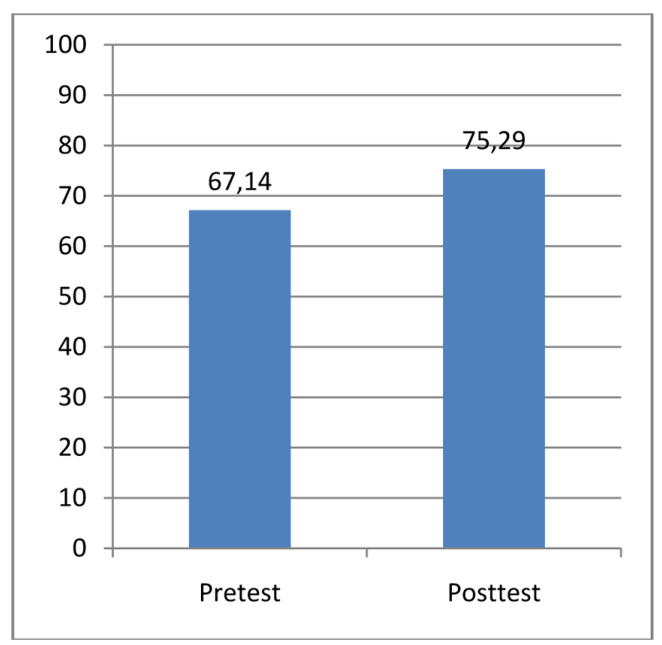

Gambar 1. Grafik Nilai Pretest dan Posttest Kelompok Eksperimen

Untuk mendapatkan simpulan yang lebih akurat, perbedaan nilai tersebut diuji statistik. Uji yang digunakan adalah uji-t. Uji beda ini perlu dilakukan untuk mengetahui apakah perbedaan tersebut hanya suatu kebetulan ataukah memang benar-benar signifikan.
Uji- $t$ terhadap nilai pretest dan nilai posttest peserta didik yang dijadikan sampel mendapatkan nilai $t$ hitung sebesar -12,745. Dalam uji-t $t$, hasil negatif atau positif tidak menjadi masalah. Yang diperhitungkan adalah angkanya. Nilai $t$ hitung $(-12,745)$ lebih besar dari $t$ tabel $(2,011)$ sehingga Ha diterima. Nilai tersebut signifikan pada taraf 0,000. Angka tersebut jauh di bawah 0,05 sehingga dapat dinyatakan bahwa ada perbedaan yang berarti antara nilai pretest dan nilai posttest.

Sebagaimana dijelaskan di bagian sebelumnya, nilai rata-rata kemampuan awal sebesar sebesar 67,14 meningkat 8,15 sehingga menjadi 75,29 . Perbedaan 8,15 itu ternyata signifikan sehingga dapat dinyatakan juga bahwa peningkatan nilai peserta didik signifikan. Ada pengaruh perlakuan penelitian yang signifikan terhadap hasil belajar peserta didik. Dengan demikian, dapat disimpulkan bahwa media Powerpoint tanpa animasi efektif digunakan dalam pembelajaran menulis laporan di SMP.

\section{Keefektifan Media Powerpoint Beranimasi Tidak Koheren}

Keefektifan media Powerpoint beranimasi tidak koheren dalam pembelajaran menulis laporan pada peserta didik kelas VIII SMP dapat dilihat dari perbedaan kemampuan awal peserta didik dengan kemampuan akhir peserta didik setelah mengikuti pembelajaran. Kemampuan awal peserta didik ditunjukkan oleh hasil pretest sedangkan kemampuan akhir ditunjukkan oleh hasil posttest. Keefektifan media ditentukan melalui uji beda kedua nilai tersebut.

Dalam penelitian ini, media Powerpoint beranimasi tidak koheren digunakan dalam pembelajaran menulis laporan di kelas VIII D SMP Negeri 1 Kawunganten dan VIII A SMP Sultan Agung Kawunganten. Kedua kelas tersebut diberi pretest dan posttest.

Media powerpoint beranimasi tidak koheren dikatakan efektif digunakan dalam pembelajaran apabila peserta didik mengalami peningkatan kemampuan menulis laporan yang signifikan. Peningkatan itu dibuktikan dengan adanya perbedaan nilai pretest dan posttest yang signifikan.

Sebagaimana telah dideskripsikan pada bagian sebelumnya, nilai pretest peserta didik 
yang belajar menulis laporan menggunakan media Powerpoint beranimasi tidak koheren sebesar 67,26 dan nilai posttest sebesar 73,11. Kedua nilai tersebut selisih 5,85.

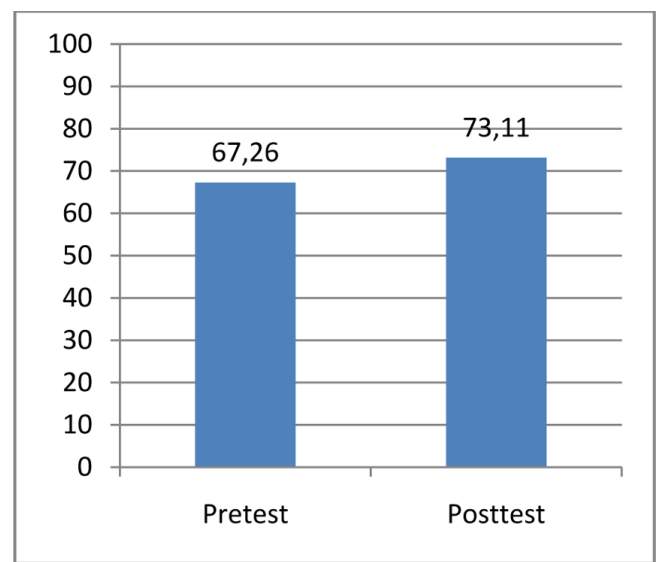

Gambar 2. Grafik Nilai Pretest dan Posttest Kelompok Kontrol

Berdasarkan perubahan nilai tersebut, tampak adanya peningkatan nilai. Ada perbedaan yang nyata antara nilai awal dengan nilai akhir. Meskipun begitu, karena nilai tersebut adalah nilai dari sampel maka perlu adanya uji statistik membuktikan apakah perbedaan itu signifikan ataukah tidak. Oleh karena itu, dilakukan uji-t.

Uji-t yang dilakukan mendapatkan nilai thitung sebesar $-6,643$. Nilai itu signifikan pada taraf $0,00(\mathrm{p}<0,05)$. Nilai $t$ hitung $(6,64)$ lebih besar dari $t$ tabel $(2,011)$ sehingga Ha diterima. Berdasarkan hasil itu, dapat dikatakan bahwa nilai pretest dan posttest benar-benar berbeda. Perbedaan kedua nilai itu signifikan. Oleh karena itu, dapat dinyatakan bahwa media Powerpoint dengan slide beranimasi tidak koheren efektif digunakan dalam pembelajaran menulis laporan di SMP.

Hasil uji hipotesis 1 dan uji hipotesis 2 menunjukkan bahwa media Powerpoint efektif digunakan dalam pembelajaran menulis laporan. Hal itu selaras dengan hasil penelitian yang dilakukan A1 Kash dan AL-Dersi (2013) dan Suaibah (2011). Kedua penelitian itu membuktikan bahwa media Powerpoint efektif digunakan dalam menyajikan materi pembelajaran. Dalam penelitian Al Kash, Powerpoint efektif digunakan untuk menyampaikan materi pembelajaran yang memiliki ide-ide kompleks dalam pembelajaran
Bahasa Inggris (A1 Kash \& Al-Dersi, 2013, p.14). Dalam penelitian Suaibah, Powerpoint efektif digunakan dalam peningkatan kemahiran menulis (Suaibah, 2011), sedangkan dalam penelitian ini powerpoint efektif digunakan untuk menyampaikan materi penulisan laporan pada peserta didik kelas VIII SMP.

Perbedaan Keefektifan Media Powerpoint Tanpa Animasi dan Media Powerpoint Beranimasi Tidak Koheren

Pada bagian pembahasan sebelumnya dinyatakan bahwa baik media Powerpoint tanpa animasi maupun media Powerpoint beranimasi tidak koheren efektif digunakan dalam pembelajaran menulis laporan pada peserta didik kelas VIII SMP Negeri 1 Kawunganten dan SMP Sultan Agung Kawunganten. Meskipun samasama efektif, keduanya dimungkinkan memiliki perbedaan keefektifan. Hal itu didasarkan pada teori multimedia yang menyatakan bahwa perbedaan tampilan multimedia (dalam hal ini slide Powerpoint) berpengaruh terhadap hasil belajar peserta didik. Oleh karena itu, dilakukan uji beda terhadap nilai posttest peserta didik yang belajar melalui media Powerpoint tanpa animasi dan media powerpoint beranimasi tidak koheren.

Perbedaan keefektifan kedua jenis tampilan media dilihat dari perbedaan nilai posttest. Perbedaan nilai posttest hasil pembelajaran menggunakan media Powerpoint tanpa animasi dan nilai posttest hasil pembelajaran menggunakan media Powerpoint beranimasi tidak koheren tersebut dihitung dengan uji Anova dua arah.

Hasil uji Anova dua arah menunjukkan bahwa terdapat perbedaan yang signifikan antara nilai posttest peserta didik yang belajar menulis laporan melalui media Powerpoint tanpa animasi dan nilai posttest peserta didik yang belajar menulis laporan menggunakan media Powerpoint beranimasi tidak koheren (F hitung sebesar 6,407 yang signifikan pada taraf 0,013 ). Hasil uji beda nilai posttest tersebut menjadi dasar penyimpulan keefektifan tampilan powerpoint dalam pembelajaran menulis laporan. Karena pembelajaran pada kedua kelompok peserta didik, yakni peserta didik yang menggunakan media Powerpoint tanpa animasi dan peserta didik yang menggunakan media Powerpoint beranimasi tidak koheren, dilakukan dengan pe- 
ngontrolan dan hanya berbeda pada penggunaan media maka dapat dinyatakan bahwa perbedaan itu semata-mata disebabkan oleh perbedaan media yang digunakan. Berdasarkan hal itu, maka dapat dinyatakan bahwa tampilan media yang satu lebih efektif daripada yang lain.

Pada bagian deskripsi nilai posttest telah disampaikan bahwa rata-rata nilai posttest peserta didik yang belajar menggunakan media powerpoint tanpa animasi sebesar 75,29. Adapun rata-rata nilai posttest peserta didik yang belajar melalui powerpoint beranimasi tidak koheren sebesar 73,11. Keduanya memiliki selisih nilai sebesar 2,18. Perbedaan itu dapat tergambar dalam grafik di bawah ini.

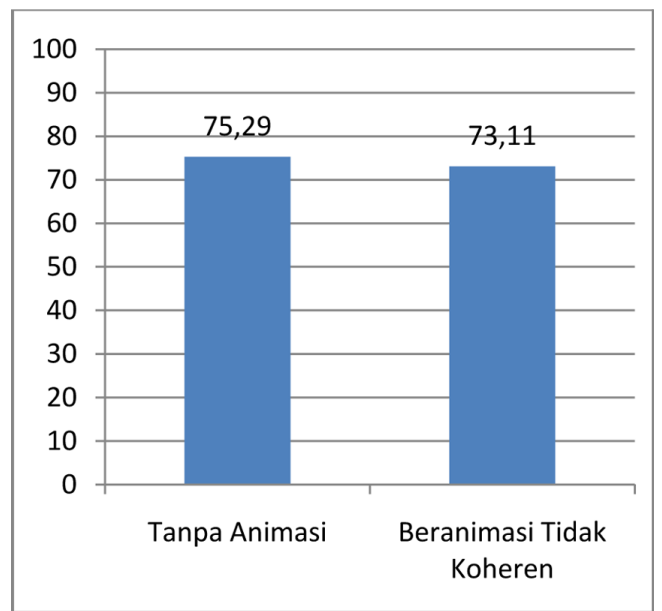

Gambar 3. Grafik Nilai Posttest Peserta Didik yang Belajar Melalui Media Powerpoint Tanpa Animasi dan Media Powerpoint Beranimasi Tidak Koheren

Media Powerpoint tanpa animasi dan powerpoint beranimasi tidak koheren memiliki isi slide (teks dan gambar) yang sama. Perbedaannya hanya terletak pada ada tidaknya animasi. Dalam hal ini, animasi yang dimaksud adalah animasi tidak koheren. Jadi, dapat dinyatakan bahwa yang mempengaruhi perbedaan hasil belajar di antara dua kelompok peserta didik tersebut adalah ada tidaknya animasi.

Hasil penelitian menunjukkan bahwa slide yang di dalamnya terdapat animasi tidak koheren lebih rendah efektivitasnya daripada slide yang tanpa animasi. Animasi tidak koheren ini dapat dikatakan sebagai noise atau peng- ganggu. Adanya noise menyebabkan efektivitas media Powerpoint berkurang.

Perbedaan Kemampuan Menulis Laporan antara Peserta Didik Sekolah Level Tinggi dan Sekolah Level Rendah

Selain menguji perbedaan keefektifan media, penelitian ini juga menguji perbedaan hasil belajar antara peserta didik sekolah level tinggi dan peserta didik sekolah level rendah. Perbedaan nilai posttest kedua sekolah dihitung dengan uji anova secara bersama-sama dengan uji beda keefektifan media.

Hasil uji beda menunjukkan bahwa terdapat perbedaan yang signifikan antara nilai posttest peserta didik sekolah level tinggi dan peserta didik sekolah level rendah. Perbedaan hasil belajar tersebut dapat dilihat dalam tabel berikut.

Tabel 6. Nilai Posttest Sekolah Level Tinggi dan Level Rendah

\begin{tabular}{cccc}
\hline Level & \multicolumn{3}{c}{ Nilai } \\
\cline { 2 - 4 } Sekolah & $\begin{array}{c}\text { Rata- } \\
\text { rata }\end{array}$ & Tertinggi & Terendah \\
\hline Tinggi & 76,94 & 87,50 & 68,00 \\
Rendah & 71,46 & 81,00 & 61,50 \\
\hline
\end{tabular}

Perbedaan nilai rata-rata peserta didik sekolah level tinggi dan level rendah mencapai 5,48 . Hal itu menunjukkan adanya perbedaan yang cukup besar di antara dua level sekolah tersebut. Selisih sebesar itu tentu tidak bisa dianggap kebetulan saja, dan memang pada kenyataannya hasil uji statistik menunjukkan perbedaan itu signifikan.

Perbedaan nilai tertinggi di antara dua sekolah yang berbeda level tersebut mencapai 6,50. Perbedaan ini lebih tinggi dibandingkan dengan selisih nilai rata-rata. Nilai tinggi sekolah level tinggi mencapai 87,50 sedangkan nilai tertinggi sekolah level rendah 81,00.

Besarnya perbedaan nilai tertinggi tersebut ternyata sama dengan perbedaan nilai terendahnya. Perbedaan nilai terendah di antara sekolah level tinggi dan level rendah tersebut juga mencapai 6,50. Selisih-selisih nilai tersebut mengambarkan perbedaan kemampuan menulis 
laporan yang cukup besar. Hal itu diperkuat lagi oleh hasil uji statistik yang mendapatkan nilai $\mathrm{F}$ sebesar 40,521 dan signifikan pada taraf 0,00. Karena $F$ hitung $(40,521)$ lebih besar daripada $F$ tabel $(3,93)$, Ha yang menyatakan ada perbedaan yang signifikan antara hasil belajar peserta didik sekolah level tinggi dan peserta didik sekolah level rendah diterima. Artinya, pada pembelajaran menulis laporan menggunakan media powerpoint tanpa animasi dan powerpoint beranimasi tidak koheren, ada perbedaan yang signifikan antara hasil belajar peserta didik sekolah level tinggi dan peserta didik sekolah level rendah.

Dalam proses pembelajarannya, kedua kelompok peserta didik ini diperlakukan sama. Artinya, ada pengontrolan, termasuk dalam hal penggunaan media. Pada tiap sekolah diambil dua kelas sebagai sampel. Satu kelas diajar menggunakan media Powerpoint tanpa animasi, dan satu kelas lainnya diajar menggunakan media Powerpoint beranimasi tidak koheren. Dengan demikian, level sekolah mempengaruhi hasil belajar peserta didik.

Interaksi Antara Media dan Level Sekolah dalam Pembelajaran Menulis Laporan

Hasil penelitian menunjukkan bahwa baik media maupun sekolah mempunyai pengaruh terhadap hasil belajar menulis laporan pada peserta didik kelas VIII. Meskipun begitu, antara media dan sekolah tidak terjadi interaksi. Hal itu ditunjukkan oleh hasil uji Anova dua arah yang pada bagian uji interaksi mendapatkan nilai F sebesar 1,378. Nilai itu memiliki signifikansi sebesar 0,243 . Karena $F$ hitung $(1,378)$ lebih kecil daripada $F$ tabel $(3,93)$, Ha yang menyatakan ada interaksi antara media dan sekolah ditolak. Artinya, pada pembelajaran menulis laporan di SMP Negeri 1 Kawunganten dan SMP Sultan Agung Kawunganten tidak terdapat interaksi antara media dan level sekolah walaupun keduanya memiliki pengaruh yang signifikan terhadap hasil pembelajaran.

Kenyataan tersebut menunjukkan bahwa media Powerpoint tanpa animasi lebih efektif daripada Powerpoint beranimasi tidak koheren, baik di sekolah level tinggi maupun di sekolah level rendah. Sebaliknya, hasil belajar peserta didik sekolah level tinggi lebih baik dari- pada peserta didik sekolah level rendah apapun jenis media yang digunakan. Dengan kata lain, antara media dan level sekolah tidak ada ketergantungan satu sama lain dalam mempengaruhi hasil belajar.

Kenyataan ini berbeda dengan pemikiran yang tertuang dalam kerangka pikir penelitian. Pada bagian kerangka pikir yang menjadi dasar penentuan hipotesis dinyatakan bahwa media Powerpoint akan berinteraksi dengan level sekolah sebagaimana tergambar dalam grafik berikut ini.

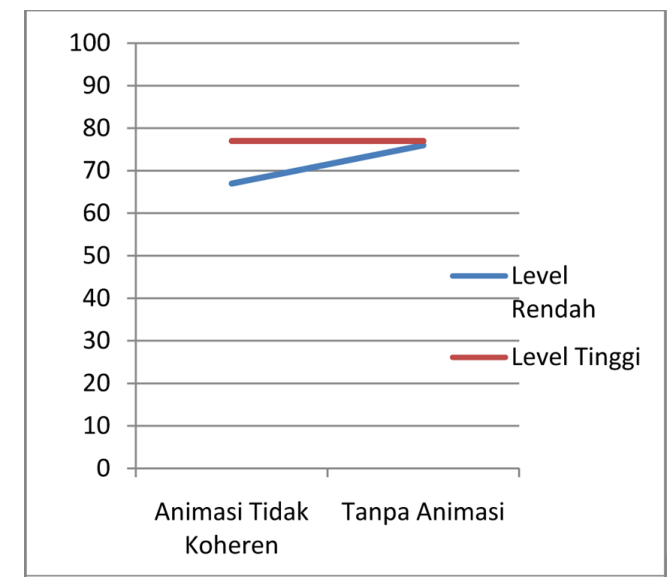

Gambar 4. Grafik Interaksi antara Media dan Level Sekolah

Gambar tersebut menunjukkan bahwa antara peserta didik level tinggi yang belajar melalui media Powerpoint tanpa animasi dan yang belajar melalui Powerpoint beranimasi tidak koheren memiliki nilai yang tidak berbeda. Peserta didik level rendah yang menggunakan media Powerpoint tanpa animasi memiliki nilai yang jauh lebih baik dibandingkan dengan peserta didik sekolah level rendah yang belajar melalui media Powerpoint beranimasi tidak koheren. Peserta didik sekolah level tinggi dapat belajar dengan baik walaupun melalui media yang tidak koheren karena memiliki pengetahuan yang bertindak sebagai kompensator terhadap ketidak-koherenan animasi. Sementara peserta didik sekolah level rendah dapat belajar dengan baik karena menggunakan media Powerpoint tanpa animasi yang memenuhi prinsip koheren. Akan tetapi, dalam kenyataannya peserta didik sekolah level tinggi yang belajar melalui media powerpoint tanpa animasi memiliki nilai 
yang lebih tinggi dari yang belajar menggunakan media Powerpoint beranimasi tidak koheren. Hal itu tampak pada grafik berikut.

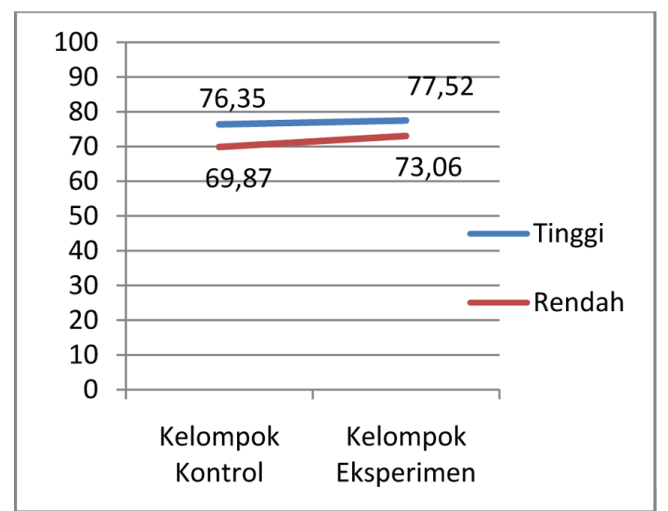

Gambar 5. Grafik Nilai Posttest Keterampilan Menulis Laporan

Pada grafik tersebut tampak bahwa nilai peserta didik yang belajar menulis laporan menggunakan media Powerpoint tanpa animasi lebih tinggi daripada nilai peserta didik yang belajar melalui media Powerpoint beranimasi tidak koheren, baik di sekolah level rendah maupun level tinggi. Pada kelompok kontrol, peserta didik sekolah level tinggi memiliki nilai rata-rata sebesar 76,35 dan peserta didik sekolah level rendah memiliki nilai rata-rata sebesar 69,87 . Pada kelompok eksperimen, peserta didik sekolah level tinggi memiliki nilai rata-rata sebesar 77,52 dan peserta didik sekolah level rendah memiliki nilai rata-rata sebesar 73,06.

Baik pada sekolah level tinggi maupun sekolah level rendah, nilai rata-rata peserta didik yang menggunakan media Powerpoint tanpa animasi lebih tinggi daripada nilai peserta didik yang menggunakan Powerpoint beranimasi tidak koheren. Pada kelompok eksperimen, nilai peserta didik sekolah level rendah tidak mendekati atau menyamai nilai yang diperoleh peserta didik sekolah level tinggi. Hal itu menunjukkan tidak ada interaksi antara media dan level sekolah dalam pembelajaran menulis laporan pada kelas VIII SMP.

Fakta tersebut dapat dikaji dengan melihat peningkatan nilai peserta didik. Keempat kelompok peserta didik tersebut memiliki peningkatan hasil belajar yang berbeda-beda. Berikut tabel peningkatan nilai peserta didik.
Tabel 7. Peningkatan Hasil Belajar Peserta Didik

\begin{tabular}{lcc}
\hline \multirow{2}{*}{ Media } & \multicolumn{2}{c}{ Level Sekolah } \\
\cline { 2 - 3 } & Rendah & Tinggi \\
\hline Tanpa Animasi & 7,19 & 9,11 \\
Beranimasi Tidak & 3,7 & 8,00 \\
Koheren & \\
\hline
\end{tabular}

Pada tabel tersebut, tampak peserta didik sekolah level tinggi dengan media tanpa animasi memiliki peningkatan yang paling tinggi. Peserta didik ini memiliki hasil belajar yang lebih baik dari peserta didik dari sekolah selevel yang belajar menulis laporan menggunakan media Powerpoint beranimasi tidak koheren. Hal ini tidak selaras dengan pemikiran yang tertuang dalam kerangka pikir penelitian, yang akhirnya juga tidak sesuai dengan hipotesis penelitian. Meskipun begitu, sebenarnya ini tidak menyimpang dari teori multimedia, khususnya prinsip perbedaan individu.

Hasil itu sesuai dengan pernyataan Mayer (2008, p.244) bahwa terdapat pendekatan alternatif terhadap teori kognitif multimedia learning yang didasarkan pada ide bahwa pengetahuan tinggi bisa semakin meningkatkan hasil dari suatu instruksi (pembelajaran menggunakan media) yang bagus". Peserta didik mampu memanfaatkan media yang baik. Lebih lanjut Mayer (2008, p.245) menjelaskan "saat tersaji pesan instruksional yang dirancang dengan baik, murid-murid berpengetahuan tinggi akan mendapatkan manfaat terbanyak dari penerapan prinsip-prinsip desain ...." Pengetahuan tinggi menjadi enhancer (peningkat) bukan sekedar sebagai compensator (Mayer, 2008, p. 244). Dengan demikian, desain multimedia yang baik tidak hanya berpengaruh besar terhadap peserta didik sekolah level rendah tetapi juga terhadap peserta didik sekolah level tinggi.

\section{SIMPULAN}

Berdasarkan hasil analisis data, didapatkan lima simpulan penelitian. Simpulan penelitian ini sebagai berikut. (1) Media Powerpoint tanpa animasi efektif digunakan dalam pembelajaran menulis laporan pada peserta didik kelas VIII SMP, ditunjukkan oleh adanya 
perbedaan yang signifikan antara nilai pretest dan nilai posttest kelompok eksperimen. Hal itu didasarkan pada hasil Uji- $t$ nilai pretest $t$ dan posttest yang mendapatkan nilai $t$ sebesar $-12,745$ dan $p<0,05$. (2) Media Powerpoint beranimasi tidak koheren efektif digunakan dalam pembelajaran menulis laporan pada peserta didik kelas VIII SMP, ditunjukkan oleh adanya perbedaan signifikan antara nilai pretest dan nilai posttest kelompok kontrol. Hal itu didasarkan pada hasil uji- $t$ nilai pretest dan posttest yang mendapatkan nilai $t$ hitung $=-6,643$ dan $p<0,05$. (3) Dalam pembelajaran menulis laporan pada peserta didik kelas VIII SMP, media Powerpoint tanpa animasi lebih efektif daripada Powerpoint beranimasi tidak koheren. Hal itu didasarkan pada hasil uji Anava dua arah yang mendapatkan nilai $F$ hitung untuk media sebesar 6,407 dan signifikan pada taraf 0,013 . (4) Terdapat perbedaan yang signifikan antara hasil belajar menulis laporan peserta didik sekolah level tinggi dan hasil belajar menulis laporan peserta didik sekolah level rendah. Hal itu didasarkan pada hasil uji Anava dua arah yang mendapatkan nilai $F$ hitung untuk level sekolah sebesar 40,521 dan signifikan pada taraf 0,00. (5) Tidak terdapat interaksi yang signifikan antara media dan level sekolah dalam pembelajaran menulis laporan pada peserta didik kelas VIII SMP. Hal itu didasarkan pada hasil uji Anava dua arah yang mendapatkan nilai $F$ hitung untuk interaksi antara media dan level sekolah sebesar 1,378 dan signifikan pada taraf 0,243 . Nilai $F$ hitung $(1,378)<F$ tabel $(3,93)$.

\section{Ucapan Terima Kasih}

Artikel ini disusun berdasarkan tesis yang telah diujikan dan direvisi. Oleh karena itu, saya mengucapkan terima kasih kepada pembimbing Dr. Tadkiroatun Musfiroh dan dewan penguji tesis yang telah memberi masukkan dan saran terhadap tesis saya. Dengan bantuan tersebut artikel hasil penelitian ini dapat diwujudkan.

\section{DAFTAR PUSTAKA}

Arsyad, A. 2013. Media Pembelajaran (Rev. ed.). Jakarta: PT. Raja Grafindo Persada.

Ghozali, I. 2009. Aplikasi Analisis Multivariate dengan Program SPSS. Semarang: Badan Penerbit Universitas Diponegoro.

Indriana, D. 2011. Ragam alat bantu media pengajaran. Yogyakarta: Diva Press.

Kemp, J. E. \& Dayton, D. K. (1985). Planning and Producing Instructional Media. New York: Harper \& Row Publiser.

Nurgiyantoro, B. 2012. Penilaian Pembelajaran Bahasa Berbasis Kompetensi. Yogyakarta: BPFE Yogyakarta.

Rusman, Kurniawan, D., \& Riyana, C. 2012. Pembelajaran Berbasis Teknologi Informasi dan Komunikasi. Jakarta: Rajawali Pers.

Suaibah. 2011. Effektivitas Penggunaan Media Powerpoint dalam Pembelajaran Keterampilan Menulis. Tesis magister, tidak diterbitkan, Universitas Islam Negeri Maulana Malik Ibrahim. 